\title{
STRENGTH AND DUCTILITY OF FORGED 1200 ALUMINUM ALLOY REINFORCED WITH STEEL PARTICLES
}

\author{
S. O. Adeosun ${ }^{1}$, A. Oyetunji² and E. I. Akpan ${ }^{3, *}$

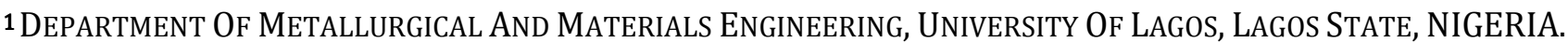

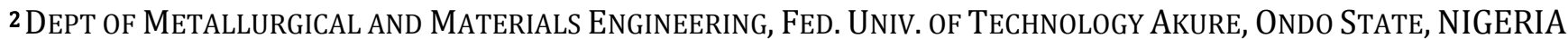

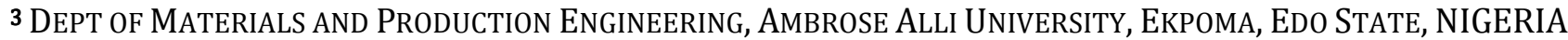

Emailaddresses.1amsonoluropo@yahoo.com,2akinlabioyetunji@yahoo.com³emma_eia@yahoo.com

\begin{abstract}
Strength and ductility responses of forged AA1200 aluminum alloy reinforced with steel particles have been

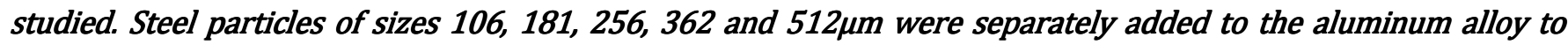
produced cylindrical shape samples, which were homogenized at $420^{\circ} \mathrm{C}$ for 10 hours, further processed through upset forging at $32^{\circ} \mathrm{C}$ and finally annealed at $470^{\circ} \mathrm{C}$ for 8 hours. Results show that forged composites with $106 \mu \mathrm{m}$ had a tensile strength of 280MPa and ductility of 1.75 after 10 percent reduction and subsequent annealing. With $50 \%$ reduction and fine-sized steel particles $(512 \mu \mathrm{m})$ in aluminum alloy, tensile strength dropped to 160MPa without significant decrease in ductility (1.7). Microstructure of cast samples show the presence of fine Fe particles at grain boundaries after annealing with most of the particles in solid solution. $\mathrm{Al}_{3} \mathrm{Fe}$ and AlFeSi intermetallics were also present in the matrix with significant influence on the mechanical properties.
\end{abstract}

Keywords: Aluminum alloy; annealing; ductility; strength; iron particle.

\section{INTRODUCTION}

Structural components made from aluminum alloys are vital to the aerospace, automobile and building industries because of their light weight, high strength, good formability and high corrosion resistance. However, the aluminum alloys system exhibit poor tribological properties. The desire in the engineering community to develop new materials with greater wear resistance and better tribological properties without compromising the strength to weight ratio, can be achieved using metal matrix composites [1].Discontinuously reinforced aluminum matrix composites are fast emerging as engineering materials and competing with common metals and alloys because of its higher specific strength, specific modulus and good wear resistance as compared to ordinary unreinforced alloys [1]. Pure aluminum has weak matrices, but the presence of reinforcing particles alters the matrix dislocation structure during deformation, resulting in significant matrix strengthening. Silicon Carbide, Iron - ore, steel dust, titanium oxide, aluminum oxide, iron powder, iron oxide, granulated slag and arc furnace dust have been used as reinforcement in aluminum matrix with significant improvement in stiffness and strength than its conventional alloys [2-9].

AA1200 aluminum alloy have very good atmospheric corrosion resistance and workability (they can be forged, extruded and striped into sheets), which make them useful in metal work, license plates, identification plates, kitchenware, packaging foils, containers, automotive trim, heat exchanger strip, radiator tubes, aircraft and military highly stressed structures [10]. These alloys usually contain iron impurities, which are detrimental to their mechanical properties and deformation characteristics. This is attributed to the formation of different ironcontaining intermetallic phases [11]. Around 17 different intermetallic phases, with general composition of either $\mathrm{Al}-\mathrm{Fe}$ or $\mathrm{Al}-\mathrm{Fe}-\mathrm{Si}$, have been found to exist in $\mathrm{Al}-\mathrm{Fe}$ based alloys depending on the presence of other elements such as magnesium and silicon [11]. Precipitation of iron containing phases during the decomposition of the supersaturated solid solution plays a vital role, especially in the process of aluminum recrystallization [12]. Apart from the 
morphology, size and type of iron-containing phases of solidification origin the effect of an ingot structure and properties of deformed materials depend on other factors, such as segregation of alloying element, the sizes of grains and dendrites cells, the substructure parameters and the degree of super saturation of the solid solution in casting.

Stir casting route because of its simplicity and easy adaptability with all shape casting processes is the most promising casting route for synthesizing welldispersed discontinuous reinforcement in the composite matrix [13]. Composites produced by stir casting have defects such as particles clustering and porosity, resulting in deleterious effect on the mechanical properties $[14,15]$. These defects can be altered by mechanical working of the composites [16] hence, the study of aluminum metal matrix composites in relation to reinforcement size, deformation processing and subsequent annealing is of outmost importance for strength improvement.

Mechanical workings of monolithic alloy are usually carried out above the recrystallization temperature as the alloy is deformed into the desired shapes and sizes. During these processes the microstructure is refined and porosity content is reduced and this in turn improves the mechanical properties. However, this may not be completely true in the case of composite materials due to incompatible deformation characteristics of the matrix and the reinforcement particles.

The effects of steel particle sizes, forging processing, and an annealing heat treatment on AA 1200 aluminum alloy produced by stir casting are examined in this current study with a view to increase strength and elongation of the alloy.

\section{EXPERIMENTAL PROCEDURE}

Samples of aluminum 1200 alloy reinforced with 10 percent weight of steel particles were cast into $20 \mathrm{~mm}$ diameter rods. The chemical composition of the aluminum alloy and the steel particles are shown in Tables 1 and 2. Steel particles of sizes 106, 181, 256, 362.5 and $512.5 \mu \mathrm{m}$ were used to reinforce the aluminum alloy. Homogenization of the solidified $\mathrm{Al}-$ Fe composite was carried out at $420^{\circ} \mathrm{C}$ for $10 \mathrm{hrs}$ for each sample.

Table 1-Chemical composition of AA1200 aluminum

\begin{tabular}{|l|l|l|l|l|l|}
\hline Element & $\mathrm{Al}$ & $\mathrm{Fe}$ & $\mathrm{Si}$ & $\mathrm{Cu}$ & $\mathrm{Mg}$ \\
\hline \% composition & 99.03 & 0.453 & 0.250 & 0.047 & 0.003 \\
\hline
\end{tabular}

Table 2-Chemical composition of steel particles

\begin{tabular}{llllll}
\hline Element & $\mathrm{C}$ & $\mathrm{Si}$ & $\mathrm{S}$ & $\mathrm{P}$ & $\mathrm{Mn}$ \\
\hline \% Composition & 0.116 & 0.101 & 0.031 & 0.022 & 0.326 \\
Element & $\mathrm{Cu}$ & $\mathrm{W}$ & $\mathrm{Ag}$ & $\mathrm{Sn}$ & $\mathrm{Co}$ \\
\% Composition & 0.243 & 0.004 & 0.005 & 0.08 & 0.01 \\
Element & $\mathrm{Ni}$ & $\mathrm{Cr}$ & $\mathrm{Mo}$ & & \\
\% Composition & 0.112 & 0.031 & 0.026 & & \\
\hline
\end{tabular}

The homogenized samples were cold forged using a pneumatic hammer to percentage thickness reductions of $10,20,30,40$, and 50 percent and annealed in a box furnace at $470^{\circ} \mathrm{C}$ for 8 hours. Control samples for each steel reinforced composite were produced without forging and heat treatment. Tensile tests were carried out on all samples using the Monsanto tensometer type " $W$ ". The values of the tensile strengths and percent elongations were calculated and recorded. Metallographic examination was carried out on each sample (20 X $20 \times 20 \mathrm{~mm})$ after the surfaces were ground with emery paper of grades 240, 320 and 600 micron in succession, polished using alumina/diamond paste and etched in a solution containing 1gram Sodium Hydroxide in $100 \mathrm{mls}$ of water for 20 secs. The prepared samples surfaces were dried in still air and the morphologies of the samples were examined with a Digital Metallurgical Microscope at X 200 magnification.

\section{RESULTS AND DISCUSSION}

\subsection{Mechanical Properties}

The effect of particle size and further treatment on maximum tensile strength of the aluminum 1200 reinforced steel composite is shown in Figure 1. Tensile strengths of composites increase with increase in filler fineness up to $256 \mu \mathrm{m}$ after which it declined. The highest tensile strength was obtained at this particle size for forged samples without annealing. Annealing of forged samples led to improvement in the maximum tensile strengths of cast composites. Samples with $106 \mu \mathrm{m}$ particle were found to have the highest maximum tensile strength after annealing of the forged sample (from 140 to $275 \mathrm{MPa}$ ). However, annealing of samples cast with $256 \mu \mathrm{m}$ sized particles did not give any improvement in tensile strength.

The elongation responses of forged and annealed composite samples are shown in Figure 2. An elongation of 1.75 is observed in annealed samples with $106 \mu \mathrm{m}$ sized steel particles. All annealed samples showed improvements in elongation over forged samples. 


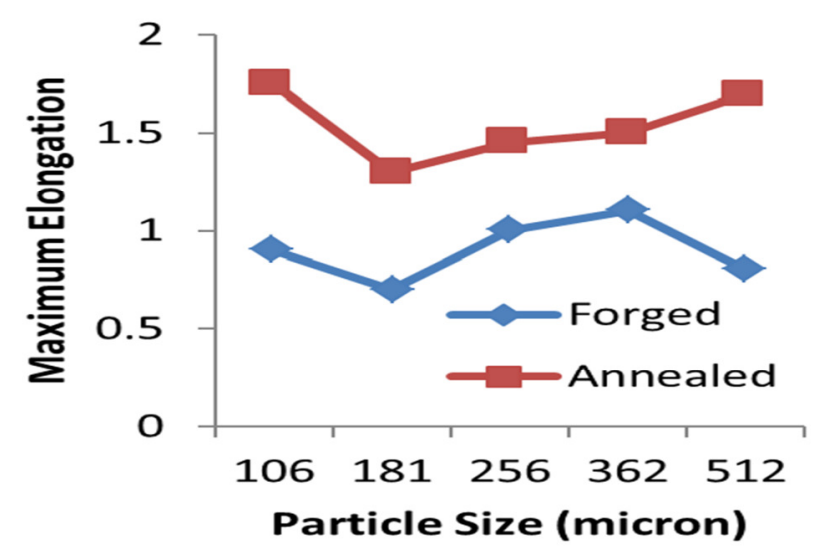

Figure 1: Tensile strengths of forged and annealed samples

\subsection{Microstructure}

Micrographs obtained from optical microscopy of AA1200 aluminum alloy -steel particles composite show the presence of three phases including aluminum matrix, alpha $\mathrm{AlFeSi}$ and $\mathrm{Al}_{3} \mathrm{Fe}$ in different volume fractions as influenced by their respective treatments [17]. Earlier research on deformation of wrought A1200 with SiC particle addition by Adeosun et al. [18] showed the presence of $\mathrm{Al}_{12} \mathrm{Fe}_{3} \mathrm{Si}$ and $\mathrm{Al}_{3} \mathrm{Fe}$ intermetallics. Bayraktar and Katundi [19] also showed the presence of $\mathrm{Al}_{3} \mathrm{Fe}$ in high purity aluminum (99.7\%) in the presence of high purity magnetite particles.

In Plate 1 the microstructure of samples cast with $106 \mu \mathrm{m}$ sized filler particles have higher volume fractions of $\mathrm{Al}_{3} \mathrm{Fe}$ crystals in the forged sample than in the annealed one. In the annealed samples coarse particles are found over the matrix surface and at grain boundaries with coarse precipitates of $\mathrm{Al}_{3} \mathrm{Fe}$ phase in the matrix (see Plate lb). AlFeSi precipitates are visible in the annealed samples and well dispersed as compared to the forged sample. In addition to the strengthening effect of these coarse iron particles, the increase in tensile strength and tensile elongation observed in the annealed samples (see Figures 1and 2) may be attributed to the presence of this crystal and its even distribution in the matrix. Authors have reported that the combined effect of grain refinement accompanying increase in iron content and the formation, precipitation and distribution of hard AlFeSi related intermetallic compounds at the grain boundaries of $\mathrm{Al}$ alloy during solidification could lead to improvement in mechanical properties [20 - 23].

Forged samples with $181 \mu \mathrm{m}$ sized iron particles show the presence of $\mathrm{AlFeSi}$ and $\mathrm{Al}_{3} \mathrm{Fe}$ crystals with $\mathrm{Fe}$ particles at the grain boundaries (see plate $2 \mathrm{a}$ ). There is a greater precipitation of fine crystals of $\mathrm{Al}_{3} \mathrm{Fe}$ in the

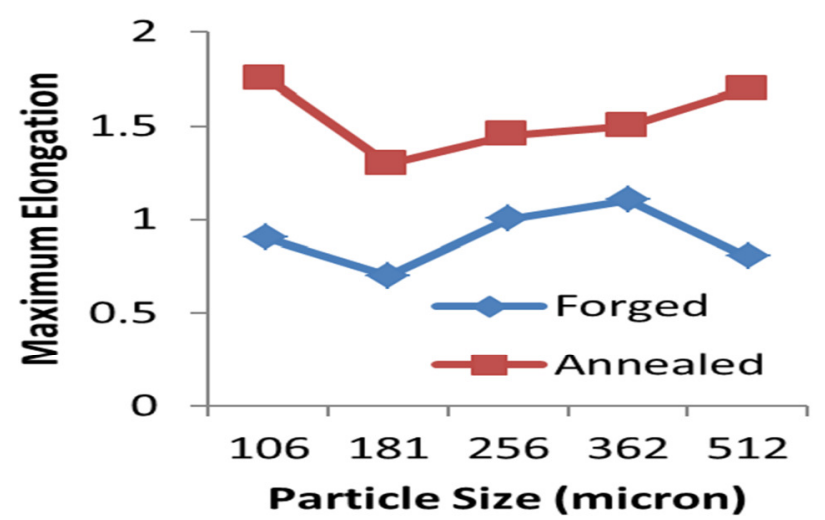

Figure 2: Maximum elongation of forged and annealed samples

annealed matrix (see Plate 2b) compared to the unannealed forged sample. The $\mathrm{Al}_{3} \mathrm{Fe}$ crystals tend to cluster while the AlFeSi crystals scattered over the matrix with retained deformation features. Annealed samples showed appreciable improvement in both maximum tensile strength and elongation (see Figures 1 and 2) over that of forged sample, which may be attributed to the presence of deformation features (which serve as dislocation barriers) and the distribution of AlFeSi crystals in the microstructure. The presence of $\mathrm{Al}_{3} \mathrm{Fe}$ crystals and incoherent precipitates of AlFeSi related intermetallics have been observed to improve elongation [18].

Plate $3 \mathrm{a}$ shows the microstructure of AA1200 aluminum sample containing $256 \mu \mathrm{m}$ iron particles forged to 30 percent reduction and annealed. In the forged matrix most of the Fe particles were absorbed leaving few but well-dispersed particles at the grain boundaries. In the annealed sample the crystals of $\mathrm{Al}_{3} \mathrm{Fe}$ and $\mathrm{AlFeSi}$ are of equal proportion but much finer than those observed in forged sample. The annealed samples did not show any improvement in tensile strength but a considerable improvement in elongation (45\%) an indication of effective even distribution of incoherent particles in the matrix.

Plate 4 shows the morphology of aluminum samples containing $362.5 \mu \mathrm{m}$ sized Fe particles forged and annealed. In the forged matrix, crystals of $\mathrm{Al}_{3} \mathrm{Fe}$ have higher volume fraction and $\mathrm{Fe}$ particles are distributed at grain-boundaries (see Plate 4a). The annealed matrix contained very fine crystals of $\mathrm{Al}_{3} \mathrm{Fe}$ and AlFeSi in equal proportion. The fine Fe particles are found at grain boundaries and are well-dispersed in the matrix (see Plate 4b). These samples show inferior strength (Figure 3 ) and elongation compared to all other samples. 


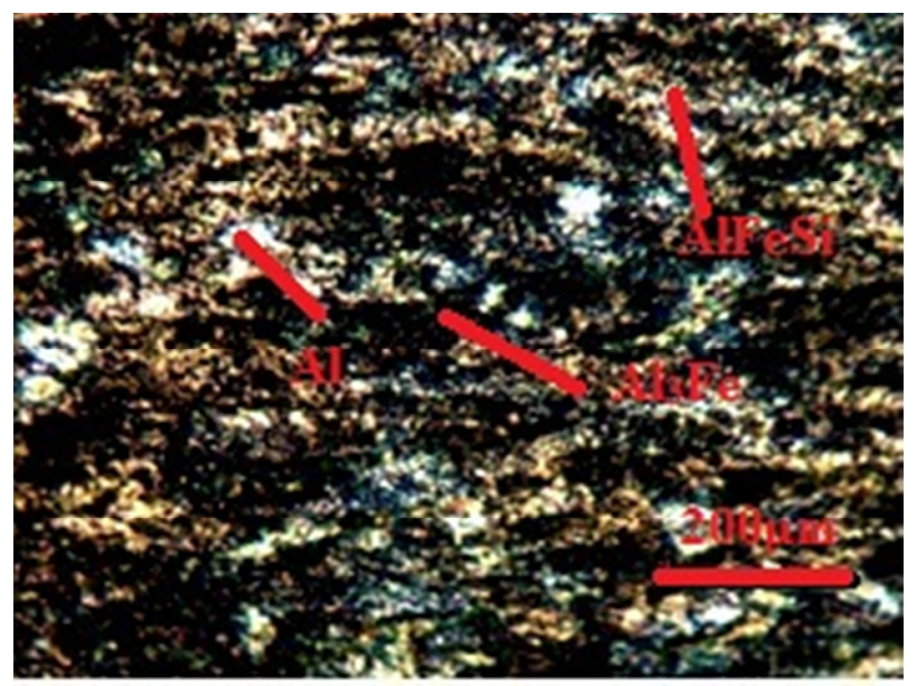

(a)

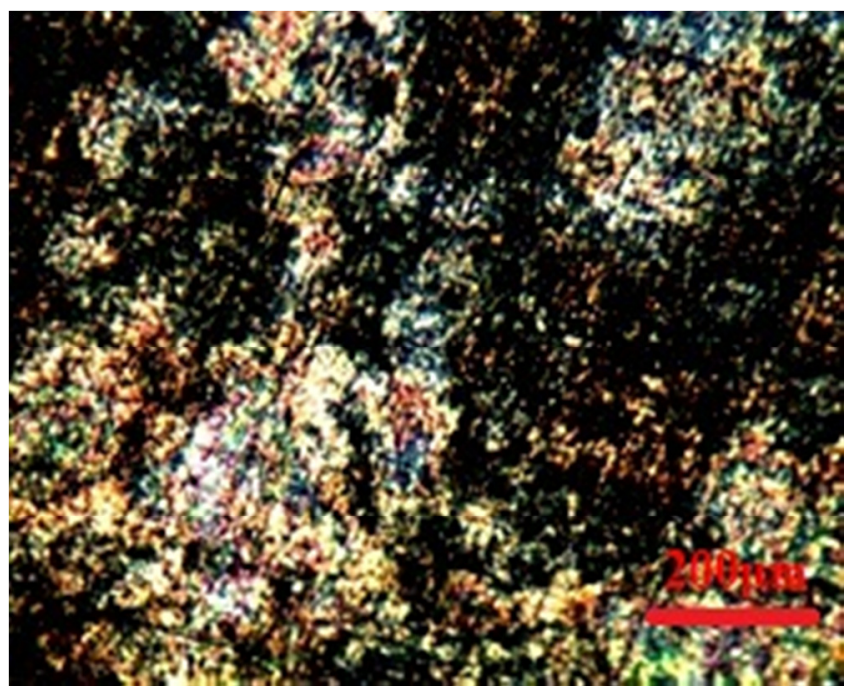

(b)

Plate1: Structure of AA1200 aluminum alloy with $106 \mu \mathrm{m}$ Fe and $10 \%$ reduction a) Forged and b) Forged and

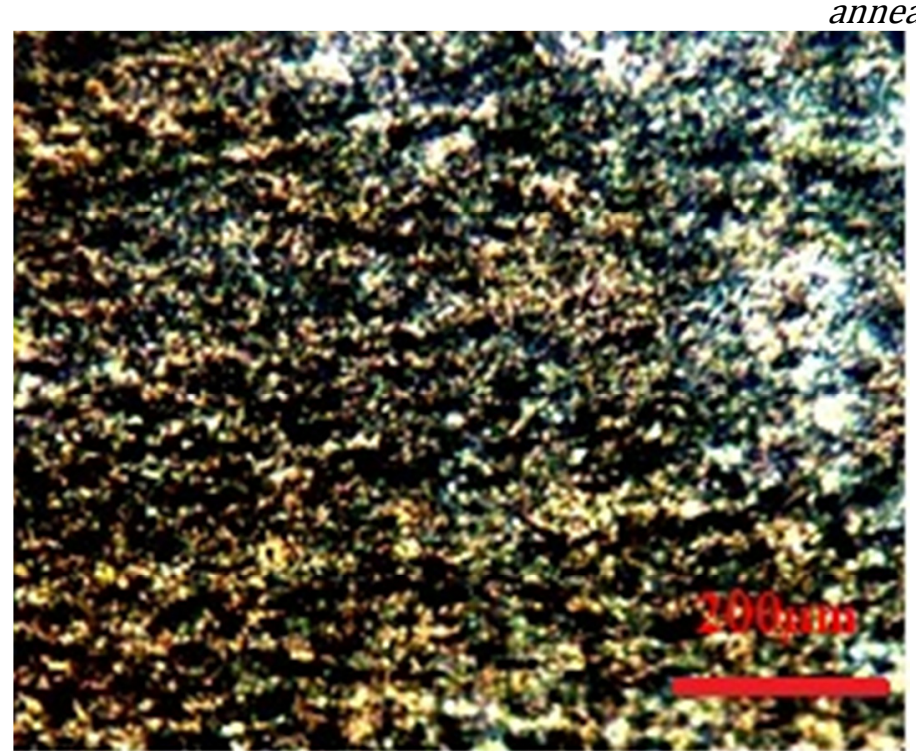

(a)

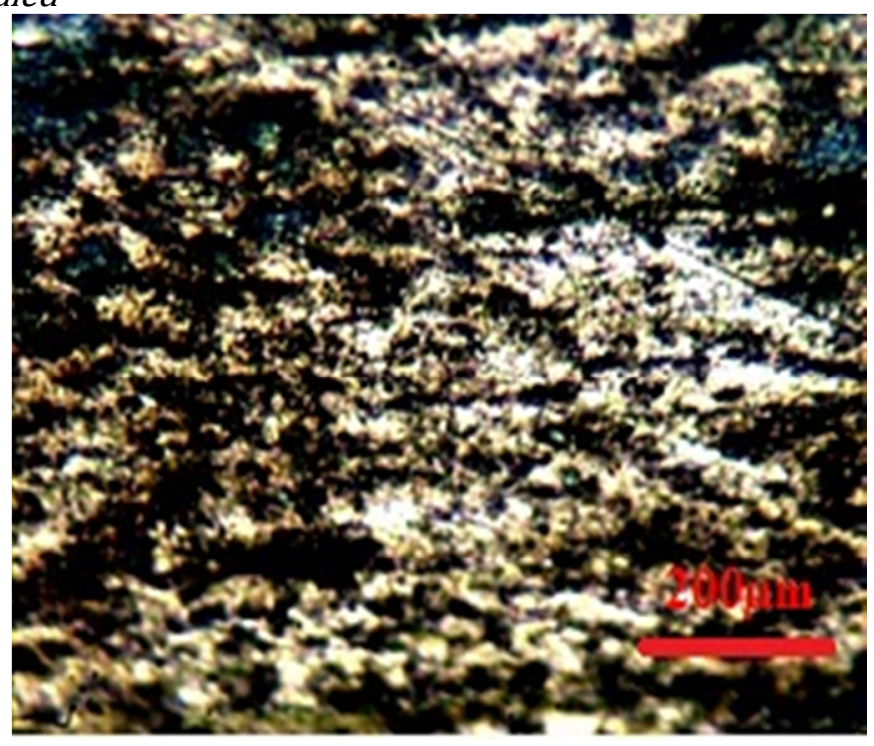

(b)

Plate 2 Matrix structure of AA1200 aluminum alloy with $181 \mu \mathrm{m}$ Fe and 20\% reduction a) Forged and b) Forged and annealed

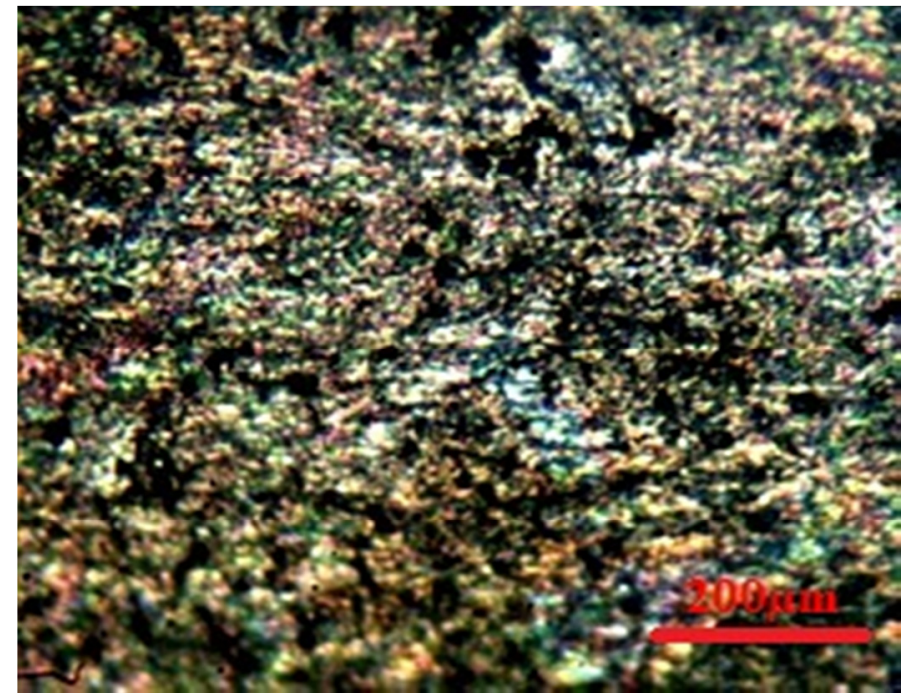

(a)

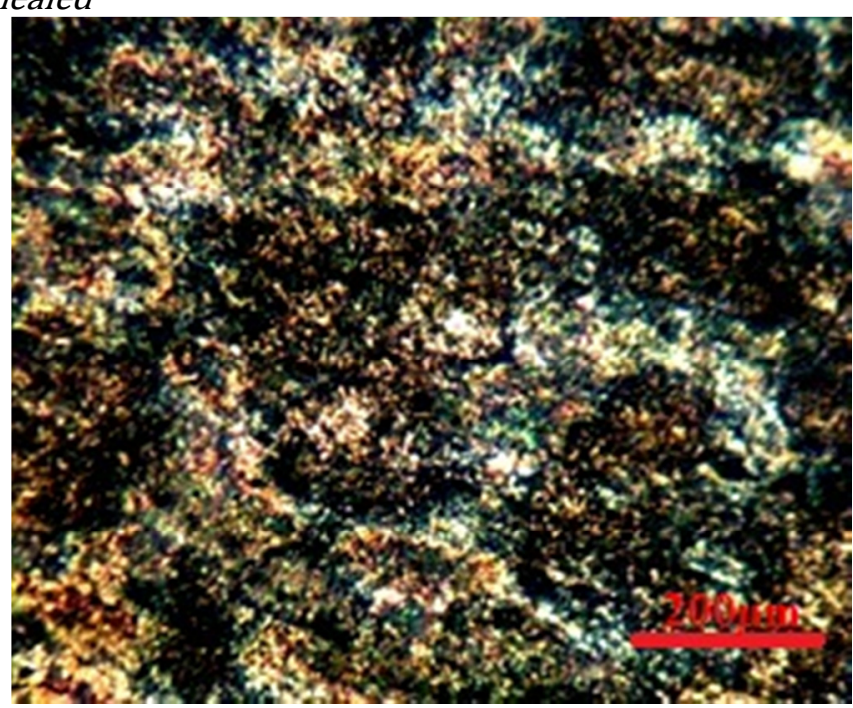

(b)

Plate3 Matrix structure of AA1200 aluminum alloy with $256 \mu \mathrm{m}$ Fe and $30 \%$ reduction a) Forged and b) Forged and annealed 


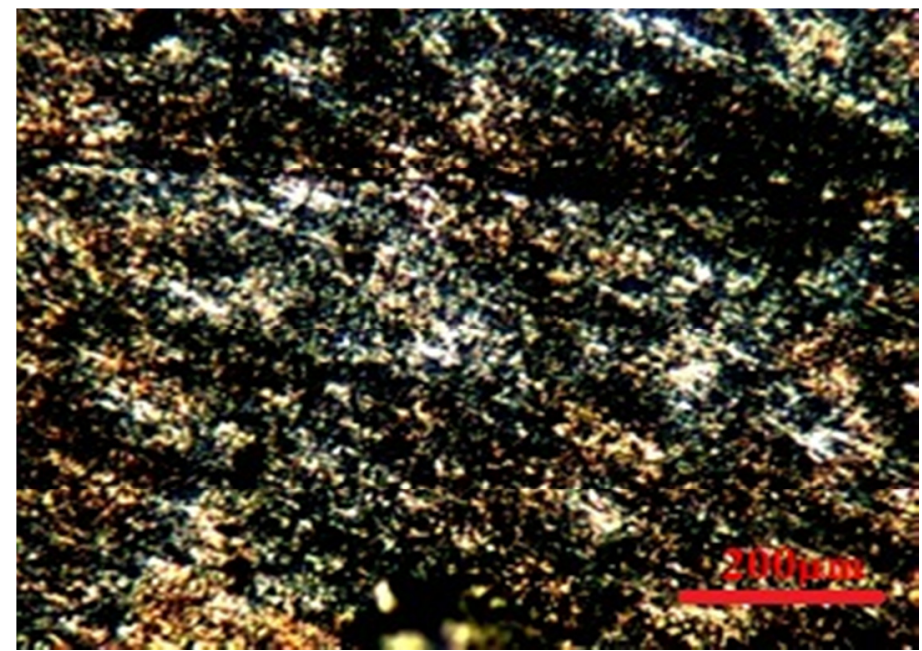

(a)

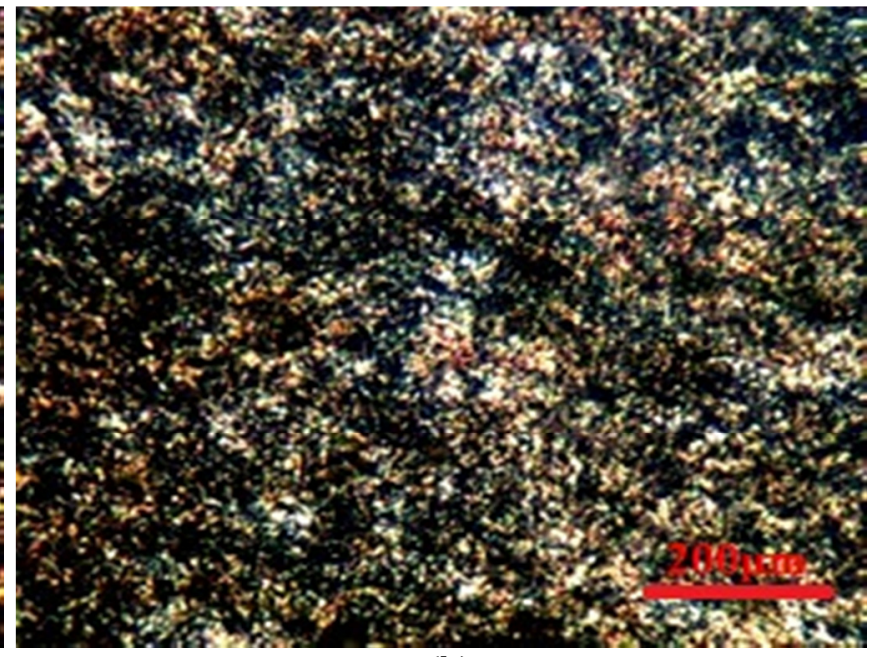

(b)

Plate 4 Matrix structure of AA1200 aluminum alloy with $362.5 \mu \mathrm{m}$ Fe and $40 \%$ reduction a) Forged and b)

Forged and annealed

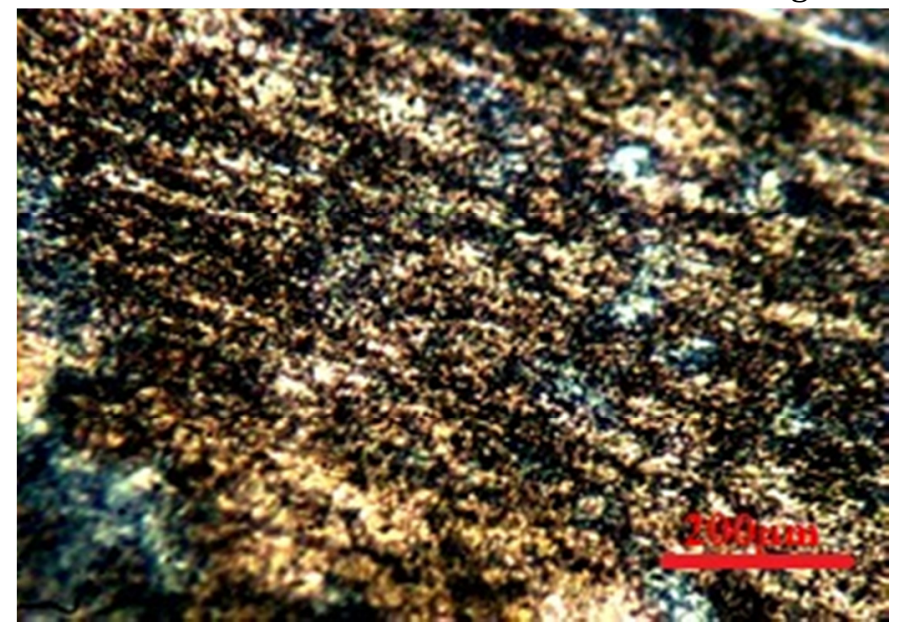

(a)

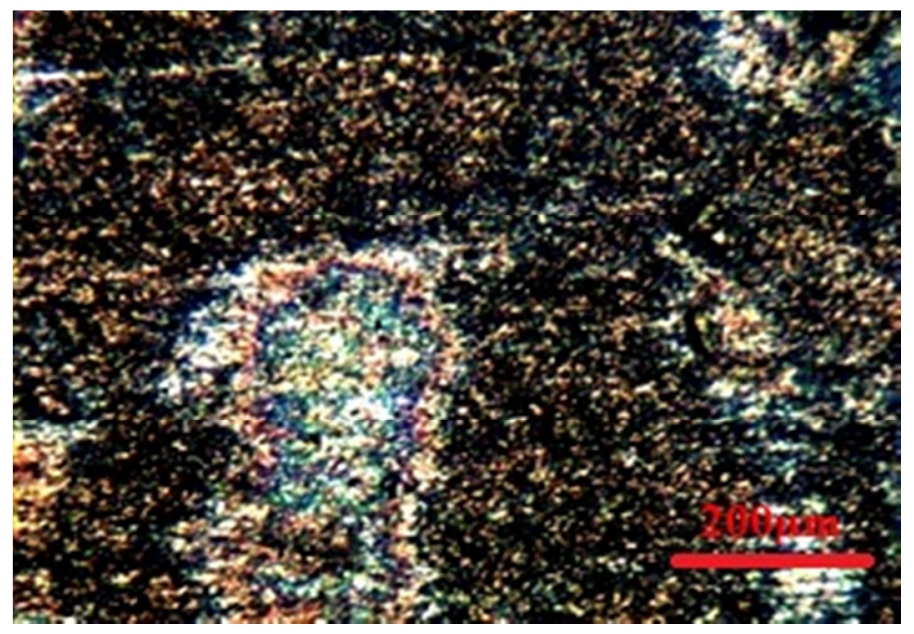

(b)

Plate 5: Matrix structure of AA1200 aluminum alloy with $512.5 \mu \mathrm{m} \mathrm{Fe}$ and $50 \%$ reduction a) Forged and b) Forged and annealed

Microstructure of samples having $512.5 \mu \mathrm{m}$ sized iron particles, forged with $50 \%$ reduction and annealed are shown in plate 5 . In the forged sample (Plate 5a) the volume fraction of $\mathrm{Al}_{3} \mathrm{Fe}$ crystal is higher than that of AlFeSi. The microstructures of annealed samples contain fine clustered particles of iron, which are welldispersed, alongside the precipitates of AlFeSi in the grain-boundaries of the matrix (see Plate $5 b$ ).

\section{CONCLUSION}

Tensile examination of wrought forged AA1200 aluminum-steel composite produced using stir casting showed that

1. Composites with $106 \mu \mathrm{m}$ sized iron particles had maximum tensile strength of 280MPa and ductility of 1.75 after $10 \%$ forged reduction and subsequent annealing.
2. With $50 \%$ forge reduction and fine-sized filler addition in aluminum matrix, strength dropped to $160 \mathrm{MPa}$ without significant decrease in ductility (1.7).

3. Microstructural analysis shows that matrix of AA1200 aluminum-steel composite contain Al-Fe and Al-Fe-Si intermetallics, which influence the mechanical properties of the composite. Grain refinement motivated by increase in iron content, precipitation and distribution of hard AlFeSi related intermetallic compounds at the grain boundaries of Al alloy during solidification was found to improve the mechanical properties of the new composite material.

\section{ACKNOWLEDGMENT}

The authors wish to acknowledge the effort of the entire technologists in Department of Metallurgical 
and Materials Engineering Laboratory, University of Lagos, towards the success of this work.

\section{REFERENCES}

[1] Singh A. Studies on Aluminum - Iron Ore In-Situ Particulate Composite, Thesis, Department of Metallurgical \& Materials Engineering, National Institute of Technology Rourkela, 2010.

[2] Mahmoud, T., Mahmoud S. F. H, Zakaria, H. and Khalifa, T. A. "Effect of squeezing on porosity and wear behaviour of partially remelted A319/20 vol.\% SiCpMMCs", J. Mechanical Engineering Science, Vol. 222, Number C3, pp. 295-303, 2008.

[3] Qian, L., Wang, H. Z. G., Toda H. and Kobayashi, T. "Effect of reinforcement volume fraction on the thermo-mechanical fatigue behavior of SiCW/6061Al composites", Materials Science and Engineering $A$,Vol. 357 Number (1-2), pp. 240-247, 2003.

[4] Aigbodion, V. S. and Hassan, S. B. "Effects of silicon carbide reinforcement on microstructure and properties of cast $\mathrm{Al}-\mathrm{Si}-\mathrm{Fe} / \mathrm{SiC}$ particulate composites", Materials Science and Engineering A, Vol. 447, pp. 355-360, 2007

[5] Narayanasamy, R., Ramesh, T., Pandey, S. K. and Pandey, K.S. "Effect of particle size on new constitutive relationship of aluminium-iron powder metallurgy composite during cold upsetting, Materials and Design, Vol. 29, pp.1011-1026, 2008.

[6] Narayanasamy, R., Ramesh, T. and Pandey, K. S. Some aspects on strain hardening behaviour in three dimensions of aluminium-iron powder metallurgy composite during cold upsetting, Materials and Design, Vol. 27, pp. 640-650, 2006

[7] Narayanasamy, R., Ramesh, T. and Pandey, K. S. "Some aspects on cold forging of aluminium-iron powder metallurgy composite under triaxial stress state condition", Materials and Design,Vol. 29, pp. 891-903, 2008.

[8] Grabowski, A., Formanek, B.,Sozanska, M.,Janicki, D.,Nowak, M. "Laser remelting of Al-Fe-TiO powder composite on aluminium matrix", Journal of Achievements in Materials and Manufacturing Engineering, Vol. 33, Number 1, pp.78-85, 2009.

[9] Olszówka-Myalska, A., Szala, J. and Cwajna, J. "Characterization of iron aluminides formed in situ in an aluminium matrix composite", Materials Characterization, Vol. 56, pp. 379-383, 2006.

[10] Aalco. 2012. Aluminium Alloy 5L34 'F' / 'O' - 1200 Obsolete 'data sheet', www.aalco.co.uk, Accessed January 12, 2012

[11] Orozco-González P., Castro-Román, M. LópezCuevas, J., Hernández-Rodríguez, A., Muñiz-Valdez, R., Luna-Álvarez S. and Ortiz-Cuellar, C. "Effect of iron addition on the crystal structure of the aAlFeMnSi phase formed in the quaternary Al-Fe-MnSi system", Revista De Metalurgia, Vol. 47, Number 6, pp. 453-461, 2011
[12] Belov, N.A., Aksenov, A.A. and Eskin, D.G. Iron in aluminium alloys, New York Taylor \& Francis Inc,,1992.

[13]Ray, S. "Review: Synthesis of cast metal matrix particulate composites", Journal of Material Science, Vol. 28, pp. 5397-5413, 1993.

[14] Ghosh P. K. and Ray, S. "Influence of process parameters on the porosity content in $\mathrm{Al}(\mathrm{Mg})-\mathrm{Al}_{2} \mathrm{O}_{3}$ cast particulate composite produced by vortex method", AFS Transaction, Vol. 88, pp. 775-782, 1980.

[15] Behera, R. Das, S., Chatterjee, D., Sutradhar, G. "Forgeability and Machinability of Stir Cast Aluminum Alloy Metal Matrix Composites", Journal of Minerals \& Materials Characterization \& Engineering, Vol. 10, Number 10, pp.923-939, 2011.

[16] Fard, R. R. and Akhlaghi, F. "Effect of extrusion temperature on the microstructure and porosity of A356-SiCp composites", Journal of Materials Processing Technology, Vol. 187-188, Number 12, pp. 433-436, 2007.

[17] Brandes E. A. and Brook G. B. Smithells Light Metals Handbook, Great Britain: Reed Educational and Professional Publishing Ltd, 1998.

[18] Adeosun, S. O. Balogun, S.A., Sanni O. S. and Ayoola, W.A. "Improving the Strength and Ductility of Wrought Aluminum through Particle addition", Proceedings of Materials Science and Technology (MS\&T), October 25-29, pp.1918 - 1928, 2009.

[19] Bayraktar, E. and Katundi, D. “Development of a new aluminium matrix composite reinforced with iron oxide $\left(\mathrm{Fe}_{3} \mathrm{O}_{4}\right)$ ", Journal of Achievements in Materials and Manufacturing Engineering, Vol.38, Number 1, pp. 7-14, 2010.

[20] Khraisat, W. and Abu Jadayil W."Strengthening Aluminum Scrap by Alloying with Iron", Jordan Journal of Mechanical and Industrial Engineering, Vol. 4, Number 3, pp.372 - 377, 2010

[21] Mrówka-Nowotnik, G., Sieniawski, J. and Nowotnik A.,"Tensile properties and fracture toughness of heat treated 6082 alloy", Journal of Achievements in Materials and Manufacturing Engineering, Vol. 17, Number 1-2, pp. 1-2, 2006.

[21] Siddiqui, R.A., H.A. Abdullah, K.R. Al.-Belushi, (2000). Influence of aging parameters on the mechanical properties of 6063 aluminium alloy, Journal of Materials Processing Technology, Vol. 102, Number 1-3, pp. 234-240, 2000.

[22] Sha, G., K. O’Reilly, B. Cantor, J. Worth, R. Hamerton, (2001). Growth related phase selection in a 6xxx series wrought Al alloy, Materials Science and Engineering A, Vol. 304-306, pp. 612-616, 2001. 